\title{
Industrial Advertising Effects and Budgeting Practices
}

\author{
What is known about the effects of industrial advertising? \\ And how does this information affect \\ budget decisions?
}

$\mathbf{T}$

HE industrial sector has long been regarded as the stepchild of marketing in terms of the amount of research effort devoted to its problems. There are, however, indications that the situation may be changing. Research on industrial/organizational buying behavior is growing, and a considerable body of empirical knowledge about processes surrounding the innovation and diffusion of industrial technologies and products has been developing.' This article is concerned with a different set of issues: those surrounding the determination of expenditure levels for industrial advertising. The purpose here is two-fold: (1) to review the available research relating to the effects of industrial advertising, and (2) to examine practices currently used in budgeting industrial advertising in light of what is known about advertising response and costs in this field.

Estimates of total industrial advertising volume are not readily available because of the lack of relevant aggregate data and the vagaries of definting what constitutes "industrial advertising." However, N. W. Ayer estimated that industrial advertising totaled $\$ 925$ million in $1973 ;^{2}$ and Marsteller, chairman of one of the major advertising agencies in the industrial marketing field,

1. See, for example, Frederick E. Webster, Jr. and Yoram Wind, Organizational L ying Behavior (Englewood Cliffs, N. J: Prentice-Hall, 1972); and James M. Utterback. "Innovation in Industry and the Diffusion of Technology," Science, February 14, 1974, pp. 620-626.

2. N. W. Ayer \& Sons, Inc., Industrial Advertising: Past, Present and Future (Philadelphia. 1974), p. i.

Journal of Markating, Vol. 40 (January 1976), pp. 16-24. has indicated that there are $300-500$ firms with annual industrial advertising budgets exceeding $\$ 1$ million. $^{3}$ Surveys of industrial advertising budgets show that outlays for research have been running at about $1 \%$ of expenditures for several years. ${ }^{4}$ Considering that the top 100 national advertisers alone spent $\$ 5.68$ billion in 1973 , $^{\text {s one }}$ can readily appreciate why the cumulative body of studies bearing on industrial advertising effects appears so slight in comparison to that available on consumer advertising. ${ }^{6}$

The advertising budget for the industrial marketer is typically too small to justify or support the kind of research effort required to assess the impact of advertising in a manner that would yield information relevant to expenditure decisions. This condition contributes to the skepticism of many industrial executives toward the effectiveness of advertising. Thus, advertising expenditure policy continues to be a perplexing prublem. for industrial marketing managers, and it becomes important to ask what is known about the process and effects of industrial advertising and how that knowledge relates to current budgeting practices.

3. William A. Marsteller, "Field of Industrial Advertising Gets More Competitive," Advertising Age, June 17. 1974.p. 23.

4. See, for example, Sally Strong. "Ad Budgets 74: Trend Is Still to Spend, Spend, Spend," Industrial Marketirg, Vol. 59 (February 1974), p. 57.

5. Merle: Kingman, "Top National Advertisers Hike Ad Total io $\$ 5.68$ billion." Advertising Age, Augusi 26, 1974.p. 1.

6. Advertising Research Foundation, Measuring Payou!: An Annotated Bibliography on the Dollar Effectiveness of Alvertising (New York, 1973). 


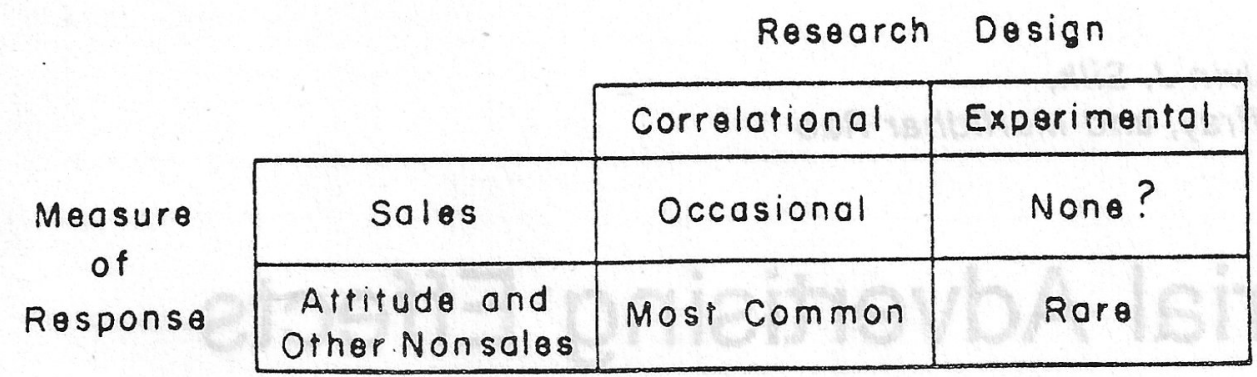

Frgure 1. Current state of industrial advertising research.

\section{Industrial Advertising Effects and Costs}

At the heart of the problem of budgeting expenditures for advertising is the lack of understanding of the nature of advertising response. This section presents a selective review of published empirical studies that provide information or clues about the effects of industrial advertising. The body of material that meets these criteria is quite small. Release of research undertaken by individual firms is infrequent, with the exception of brief, informal accounts that occasionally appear in the trade press.

Arthur D. Little, Inc. and N. W. Ayer have both recently issued reports surveying the literature in the industrial advertising field.? The Arthur D. Little report claimed that 1100 studies were uncovered, but many of the references listed dealt with consumer advertising research. In fact, only 8 studies were singled out for detailed discussion. The impression gleaned from those reviews, as well as from the present one, is that, from a methodological viewpoint, the current state of industrial advertising research can be described as indicated in Figure 1.

While only a very limited amount of empirical research is available in this area, some evidence exists that bears on each of the following important phenomena:

1. Economies of scale. Is there some relevant range in which additional increments of advertising yield increasing returns?

7. Arthur D. Little, Inc., An Evaluation of 1100 Research Studies on the Effectiveness of Industrial Advertising. A report to American Business Press, Inc. (Cambridge. Mass.. 1971); and same reference as footnote 2 .

\section{- ABOUT THE AUTHORS.}

Gary L. Lilien is assistant professor of management science, Alvin J. Silk is professor of management science, and Jean-Marie Choffray and Murlidhar Rao are doctoral students in the Alfred P. Sloan School of Management, Massachusetts Institute of Technology.
2. Threshold effects. Is there some minimum level of exposure that must be exceeded for advertising to have a discernible effect?

3. Interaction effects. Does advertising interact with other elements of the marketing mix (personal selling in particular) to produce effects that are greater than the sum of their separate effects?

This section will examine the current literature in industrial advertising with respect to the effects and costs of such advertising. Particular attention will be paid to the sales and nonsales effects and to specific cost considerations, in an attempt to answer the three questions posed above.

\section{Sales Effects}

The published literature is almost devoid of either correlational or experimental investigations of sales response to industrial advertising. A noteworthy exception is a regression analysis discussed by Weinberg. ${ }^{8}$

Weiriberg reported empirical evidence on the marketing effort-sales relationship which implied diminishing returns for that effort. He developed a multiple-equation corporate planning model that was applied to several industrial goods manufacturers. Weinberg reported that a submodel of the system relating changes in a irm's market share to its "advertising exchange rate" (the firm's advertising expenditures per dollar of sales divided by the corresponding ratio for its competitors) had been successfully used in some of this work. He presented an example in which data consisting of seven observations for an unidentified glass container manufacturer were used to estimate the relationship between annual changes in market share and the exchange rate for advertising expenditures. An excellent fit was obtained $\left(R^{2}=.966\right)$, and the form of the relationship (linear in the logarithms of both variables) implied diminishing returns to ad-

8. Robert S. Weinberg, "Multiple Factor Break-Even Analysis: The Application of O.R. Techniques to a Basic Problem of Management Planning and Control," Operations Research, Vol. 4 (April 1956), pp. 152-186. 
vertising effort. Weinberg also demonstrated how the model could be incorporated into a procedure to determine the company's relative advertising effectiveness per dollar expended and, more importantly, to find the advertising level that would maximize profit in the next year given a forecast of competitive activity and economic conditions."

What is perhaps most interesting about the Weinberg study is that it remains a rarity. It showed how quantitative advertising-sales relationships could be developed and used to help set advertising budgets. Yet there are no reports in the literature of follow-up work.

There are, however, two other areas of sales effects of advertising that have received some attention in the literature: the effect of advertising on competition and advertising's effect on sales call effectiveness. Each of these is examined below.

Effect of Advertising on Competition. The effect of advertising on competition has long been a subject of considerable interest to economists concerned with industrial organization and economic performance. The debate has centered on whether or not heavy advertising helps raise entry barriers and thereby leads to diminished levels of competition and the earning of monopoly profits. Schmalensee has reviewed a number of "direct tests" of the proposition that advertising adversely affects competition, but interpretation of the available evidence on this question remains controversial for a variety of reasons discussed by him and others. ${ }^{10}$ One of these studies, however, deserves mention here because it treated producer and consumer goods separately.

Miller reports a positive correlation between advertising intensity and industry profit rates. He examined the relation of profit rates to advertising intensity (advertising-sales ratios) plus two uther variables: concentration (share of industry output produced by the largest firms) and diversity (the extent to which firms specialize in one industry or are diversified into other industries)." Multiple linear regressions of profit rates on these three variables were reported for a sample consisting of 71 "Internal Revenue Service minor industries" (roughly the three-digit standard industrial clas-

9. Robert S. Weinberg. An Analytical Approach to Advertising Expendilure Strategy (New York: Association of $\mathrm{Na}$ tional Advertisers, 1960).

10. Richard Schmalensec. The Economics of Advertising (Amsterdam, Netherlands: North-Holland, 1972), pp. 219. 228 and Chap. 7; sec also, Julian L. Simon, Issues in the Econemics of Advertising (Urbana, Ill.: University of Illimois Press, 1970), (hatp. 9.

11. Richard A. Miller, "Market Structure and Industrial Performance: Relation of Protit Rates to Concentration. Ad. vertising Intensity, and Diversity," Joumal of Industrial Ecomemics, Vol. 28 (April 1969). pp. 104-118. sification level of aggregation) that were manufacturers of producer goods. The regression coefficient for the advertising intensity variable was positive and statistically significant, which implies that those producer goods industries that spent more on advertising tended to be those that realized higher rates of profitability. An unresolved issuc here is whether profits determined advertising rather than vice versa.

Effect on Sales Call Effectiveness. Morrill reports results that seem to indicate that advertising increases sales call effectiveness. He has carried out a large body of relevant industrial advertising research sponsored by a dozen major industriai sellers. ${ }^{12}$ Some reports have appeared that summarize his results from studies involving 129 brands of 23 products drawn from five industries (utilities, commodities, electrical/electronic, metalworking, and chemical). ${ }^{13}$ Over 40,000 telephone interviews at 17,000 buying locations were conducted during the period 1964 to 1969 . In each case, an attempt was made to locate one or more "brand-deciders" and to assess purchase behavior, attitudes toward various brands, and magazine reading habits from which advertising exposure could be inferred. Analysis of these data revealed a strong positive association between amount of advertising exposure and various measures of attitudinal and sales response. Figure 2 illustrates some of these relationships using average data for the five industrial classifications.

Morrill also found that dollar sales per salesman's call were much higher for calls made on customers who had been exposed to advertising, as compared to those who had not. Based on estimate's of the average costs of an industrial salesman's call $(\$ 50.00)$ and an advertising exposure (\$0) 16), a subsidiary analysis showed that for the average brand studied. an index of personal selling expense as a pereentage of sales declined from a level of 100 with no advertising expostures to a value of 74 for 30 exposures. ${ }^{14}$

Taken at face value, Momill's results make a strong case for industrial advertising, indicating that advertising pays off by making personal selling efferts more productive. However certain methodological questions surrounding Morrill's

12. John E. Morrill. "Industrial Advertising Pays Off," Hanurd Business Review, Vol. 48 (March-Apt il 1970) pr. 4-14.

13. Mc (haw-Hill Book Co." "How Advertising Works in Today' Marketplaco" (New York, January 1971); and Mclitaw llill Benk (o., "Advertising's (hallenge lo Man. agement A Second Repurt on the Morrill Study" iNew York. Seplembet 1971)

1.t Me ciatu-Mill, "Advertising's Challenge," same refer ence as lexinote 13, p. 0 . 


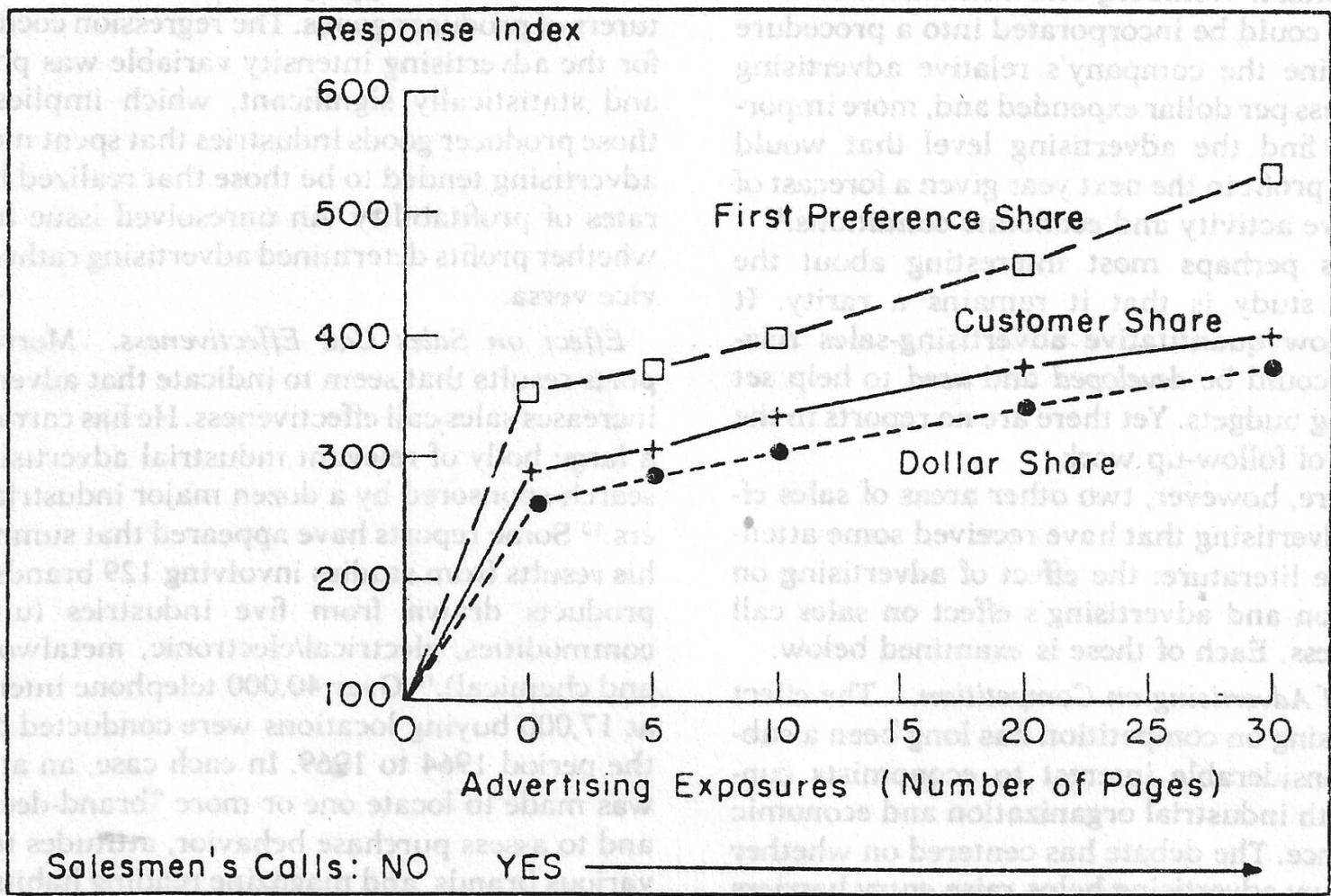

Source: Plotted from data posented in "Advertising's Challenge to Management: A Second Peport on the Morrill Study" (Now York: McGraw-Hill Book Co., Soptomber 1971), p. 8.

Figurg 2. Levels of response associated with varying a mounts of exposure to advertising and salesmen's calls.

studies deserve mention. Morrill's inferences about the effectiveness of advertising are derived from ex post facto comparisons of exposed and unexposed groups. It is well known that this "preexperimental" design is prone to several threats to internal and external validity. 15 Morrill refers to a computer-based method for "matching" the exposed and unexposed groups. ${ }^{16}$ Since Morrill's conclusions about advertising's impact depend on the equivalence of such groups (exclusive of advertising exposure), the adequacy of this matching procedure is critical and it is unfortunate that details of the method have not been published. Further, the practice of obtaining response data and self-reports of exposure in the same interview can lead to spuriously high associations between these two types of measures. ${ }^{17}$

Nonetheless, the sheer bulk and consistency of the evidence from Morrill's studies is impressive, and by no means can it be overlooked. The most important finding is that advertising used in conjunction with personal selling can reduce total selling costs. Morrill also refers to evidence of threshold effects in response to advertising. He

15. Donald T. Camphell and Julian C. Stanley, Experi. mental and Qtwasi-Experimental Designs for Research (Chicago: Rand-McNally, 1963), pp. 12-14.

16. Same reference as f(x)tnote 12, p. 6.

17. Same reference as foumule 15, p. 67 . suggests that less than a certain (smail) level of exposure (a frequency of about five advertising pages per year) seems to have no effect. ${ }^{18}$

\section{Attitudinal and Nonsales Measures of Response}

Research that focuses on attitudinal and other nonsales measures of response to industrial advertising is, as noted earlier, by far the most common type undertaken. Proprietary studies of this kind are done routinely, and occasionally partial accounts of them are made public. ${ }^{19} \mathrm{Al}$ though these studies are seldom reported in sufficient dectail to permit analvsis and to provide a basis for generalization, there are some notable exceptions.

Morrill's comprehensive studies provide support for the widely held view that a principal function of industrial acivertising is to make buyers more receptive to the advertiser's salesmen by creating a favorable impression of the

18. Same reference as foumote 12, p. 14

19. Sec, for example, James W. Mason, "The Communication Effect of an Industrial Advertising Campaign," Joumal of Advertising Research. Vol. 9 (March 1969), pp. 35-37; and Harry D. Wolfe, James K. Brown, and G. Clark Thompson, Measuring Advertising Results (New York: National Industrial Conference Buard, 1962). 
firm as a supplier. ${ }^{20}$ This concept constitutes one of the major rationales for the image-building campaigns frequently undertaken by inclustrial marketers. ${ }^{21}$

Levitt conducted a controlled laboratory experiment that demonstrated the positive influence of company reputation on the effectiveness of industrial salesmen.22 Experienced business personnel (113 practicing purchasing agents and 130 engineers and scientists) were used as subjects. Participants were exposed to a ten-minute filmed sales presentatioi for a fictitious, but plausible. new product. Company reputation was manipulated by varying the name of the firm that the salesman was identified as representing. Immediately after viewing the film, and again five weeks later, subjects responded to a questionnaire that asked if they would recommend that the product be given further consideration by others in their organization and whether they themselves ivould favor adoption. As anticipated, company reputation was found to influence the favorableness of response on these measures. However, some unexpected differences were detected between the reactions of the purchasing agents and the reactions of the technical personnel. The results suggested that a seller's reputation made a difference in a salesman getting a favorable first hearing for a new product with both purchasing and technical personnel. But when it came to making an actual purchasing decision, the advantage of reputation manifested itself with the technical personnel but not with the purchasing agents.

There has been some research on industrial buyers' use of, or preferences for, different information sources in connection with studies of the adoption of new products. ${ }^{23}$ The results suggest a pattern of dimini.hing reliance on impersonal sources such as media advertising and increasing influence of salesmen and other personal sources as buyers move from the initial awareness stage through the evaluation and decision stages of the

20. Wolfe e! al., same reference as footnote 19, p. 7 .

21. See, for example. Wolfe et al., same reference as feut. note $19, \mathrm{pp} .40-101$

22. Theodore Levitt, Industrial Purchasing Behavior: A Study of Communications Effects (Boston: Division of Research, Graduate School of Business Administration, Harvard University, 1965).

23. Sec for example, Frederick E. Webster, Jr., "Informal Cornmunication in Industrial Markets." Joumal of Marketing Research, Vol. 7 (May 1970), pp. 186-189; John A. Martilla, "Word-of-Mouth Communication in the Industrial Adoption Prucess," Joumal of Marketing Research, Vol. 8 (May 1971), pp. 173-178; and Urban B. Ozanne and Gilbert A. Churchill, Jr'. "Five Dimensions of the Industrial Aduption Process," Jounial of Marketing Research, Vol. 8 (August 1971), pp. 322-328. adoption process. In this regard, Tumbull, in a study of marketing communication policies of ferrous components producers in the United Kingeden, reports "a failure of the sompanies to understand that buyers may have different communication needs and channel preferences at different stages in the buying process, and in dilferent industries." 24

\section{Advertising Cost Studies}

The preceding discussion focused on how industrial buvers and markets respond to advertising. This section examines research related to the other key element that enters into advertising expenditure discussions: cost considerations.

The issue of whether or not there are economies of scale in advertising is highly relevant not only. to determining advertising expenditure levels, but also to allocating these funds among media and markets and over time. The occurrence of economies of scale in advertising implic's that over some range of advertising, an additional unit of advertising input produces a greater marginal return than the previous equal increncent yiclded.

Schmalensee distinguishes between two sources of varying returns to scale in advertising. 2s The first he terms "technical economies," to refer (i) differences in the eflectiveness of successive exposures. The data from Morrill's studies, plotled in Figure 2, would seem to indicate essentially constant retums to scale and henee reilect the absence of any technical economies. The second valicty are "pecuniary economies," which may arise if the cost of advertising exposures changes with the total number of exposule's used. such as might occur as a conscanence of the mediat offering quantity discounts.

Ecomemies of scale in advertising are treated to sorme extent in the economics literatlare. Increasing returns to scale constitute one mechanism whereby advertising might help raise barriers to entry. The available empirical studies tend to be based on cross-sectional samples consisting either entirely of consumer goods industries or of a combination of consumer and producer goods fields. Only occasionally has the latter distinction been recognized in the analyses reported. Most of these studies are consistent in failing to support the notion of economies of scale in advertising. ${ }^{26}$

24. P W. Turnbull, "The Allecation of Resoures 10 Marketing communications in Industrial Markets." Industrial Marketing Management, Vol. 3 (October 1974), pp. 247.310.

25. Sohmalensec, same reference as furnote 10, pr. 231 . 232 .

20. (we)rge J Stigler, "The Economies of Scale," Joumal of $I$ aw and Economics, Vol. I (Ociober 1958), p o6; and Julian 1. Simon and George 14. Crain, "The Advertising 
However, sorne contrary findings have turned up in cross-sectional studies of marketing costs of indiviclual firms.

Turnbull obtained information on marketing communications expenditures and sales for a set of firms producing ferrous components whose combined output accounted for $51 \%$ of the inclustry total in the United Kingdom. ${ }^{27}$ He lound a rank order correlation of -.512 between firm size (sales) and the ratio of marketing communications expenditures to sales. Although based on only eleven observations, the coefficient approaches significance at the 05 level.

Bailey found evidence of economies of scale in a 1969 study of manufacturers' marketing costs that was conducted by the Conference Board. This study involved data obtained for 828 products, a large proportion of which were industrial goods. ${ }^{28}$ Although detailed results were not presented, Bailey states that "the large-volume marketing unit dealing either in consumer or industrial goods generally gives up less of its sales clollar to the cause of marketing than does a small-volume competitor." He goes on to observe that "there is a certain point at which differences in sales volume become critical" and indicates that for industrial products this point is "just below $\$ 30$ million." 29

It was noted earlier that Morrill demonstrated a strong interaction effect between personal selling and advertising. Evidence of this phenomenon was also found in a study of industrial firms' marketing costs carried out by McGraw-Hill and reported by Kolliner. ${ }^{30}$

Kolliner reports that the larger the role of advertising in the marketing budget, the lower that budget seems to be as a percentage of sales. In 1961, marketing cost data were obtained via a mail questionnaire from 893 industrial advertisers. The sample contained firms of various sizes from three broad industrial product categories (machinery, materials, and equipinent and supplies). Consistent with the view that advertising can increase the efficiency of personal selling. it was found that as the proportion of total sales expense spent on advertising and promotion in-

Ratio and Economies of Scale," Soumal of Aduertising Research, Vol o (September 1966), pp. 37.43. For a review, see sihmalerisec, same reference as fesenole 10. pp. 228-237; amd simon, same reference as foothote 10, chap. 1.

27. Simme reference as focmuste 24.

28. Farl L. Bailey. "Manufacturers' Marketing Custs," (ionference Board Record, Vol. 8 (October 1971), pp. 58-64.

29. Same reference as fuotnote 28, p. 60.

30. Sim A Kulliner. Jr.. "New Evidence of Ad Values," Industrial Marketing. Vol. 48 (August 1963), pp. 81-84. Sec also. McGraw-Hill Laboratory of Advertising Performance. "Advertising and the Cosi of Selling" (New York:

McGraw-Hill Book Co., July 1964). creased, total sales expense as a percentage of sales tended to decline.

Interpreting this relationship is somewhat hazardous, inasmuch as it was formed by grouping and averaging the original observations on two variables which were ratios whose numerators and denominators contain common elements. It is unfortunate that more disaggregated analyses were not undertaken. Yet some additional results were repurted which tend to confirm the basic notion that advertising contributes to marketing efficiency. The relationship between firm size (annual sales volume) and total sales expense as a percentage of sales was examined separately for firms that had expended "high" (more than 20\%) and "low" (less than 20\%) proporions of total sales expense on advertising and promotion. Figure 3 shows these relationships, which are also based on averages of grouped data.

For all four size categories, total sales expense (as a percentage of sales) was less with "high" advertising and promotion than with "low." Note that the results indicate economies of scale. The same pattern of results was observed in clata from a second, smaller study of 227 firms conducted by McGraw-Hill in 1963.31 Thus, the results from these cost studies appear to be consistent with the research on advertising response reviewed above in indicating that industrial advertising can serve to enhance the effectiveness of personal selling efforts.

\section{Budgeting Practices}

In light of the ciearth of available empirical knowledge about market response to inciustrial advertising, management in this field must ordinarily depend on some blend of judgment, experience with analugous situations, and simple rules-of-thumb guidance in setting budgets. Heuristics like "X percent of expected sales" and the "objective and task" niethod are the principal approaches to budgeting that industrial advertisers report using.

Among 557 subscribers to Industrial Marketing who responded to a 1968 mail questionnairc, the following distribution of budgeting practices was found: ${ }^{32}$

\begin{tabular}{lc} 
Wethod & \% Using \\
\cline { 2 - 2 } of sales & 24.8 \\
Task & 35.6 \\
Arbitrary & 27.7 \\
Other & 11.9 \\
\cline { 2 - 2 } & 100.0
\end{tabular}

31. McCraw-Hill, same reference as footnote 30

32. Murray Harding, "Project Future: More Advertisers Mad than (jlad about Budget Policy." Industrial Marketing. Vol. 53 (August 1968), p. 58 . 


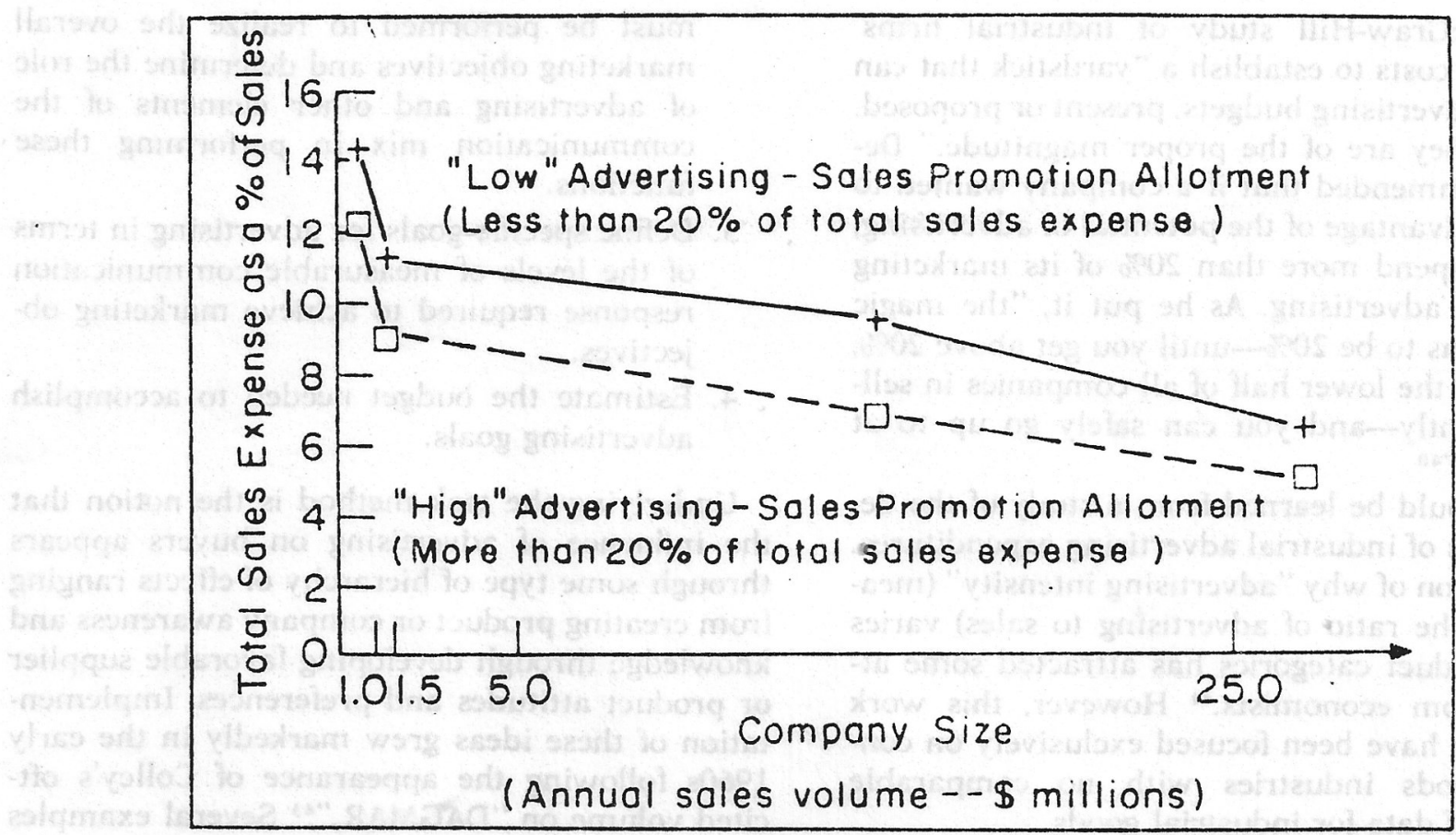

Source: Plotted from data presented in Sim A. Kolliner, "New Evidence of Ad Values," Industrial Marketing. Vol. 48 (August 1963), p. 82.

Figure 3. Relative selling costs and company size for high and low advertising-sales promotion allotmenis.

Heavy reliance on rules of thumb and the task method has also been reported in other budgeting studies on firms outside the industrial marketing sector. ${ }^{33}$ In recent years, however, measurement programs and models have made some inroads on budgeting practices in the consumer gouds field; ${ }^{34}$ it is, therefore, surprising to find that - Weinberg's worn is the only documented account of a comparable analytical method for budgeting industrial advertising that has appeared in the literature. ${ }^{35}$

\section{Heuristics}

Percent-of-sales decision rules are a pervasive influence in setting advertising budgets. Schmalensee has analyzed the conditions under which it might be optimal for a monopolist or an oligopolist to maintain a constant advertising-to-sales ratio. ${ }^{36}$ However, there have been no empirical investigations to demonstrate that the behavior of industrial advertisers' expenditures indeed are sensitive to

33. See, for example, David L. Hurwood, "How Companies Set Advertising Budgets," Conference Board Record, Vol. 5 (March 1968), pp. 34-41; Albert W. Frey, How Many Dollars for Advertising (New York: Ronald Press, 1955); and Walter Taplin, "Advertising Appropriation Policy." Economica, Vol. 26 (August 1959), pp. 227-239.

34. Seymour Banks, "Trends Affecting the Implementation of Advertising and Promotion," JOURNAL OF MARKETING, Vol. 37 (January 1973), p. 24.

35. Same reference as forinote 8 .

36. Same reference as footnote 10, Chap. 2 . key limiting requirements (e.g., the constancy of certain demand elasticities) of such a policy.

The weaknesses of percent-of-sales decision rules are well known, ${ }^{37}$ but the most fundamental objection is that they implicitly make advertising a consequence rather than a determinant of sales and profits and can easily give rise to dysfunctional policies. For example, budgeting advertising as a percentage of expected sales would ordinarily lead to reduced expenditures in an economic downturn. Yet the Buchen organization, in a correlational study, indicated that industrial advertisers who maintained their expenditures during recession periods realized better sales performance than those who did not. ${ }^{38}$ Nonetheless, some mechanism to control advertising expenditures is required, and in the absence of concrete and current measurements of advertising results, top management frequently establishes some percentage of sales or profit as a budgeting guidcline. ${ }^{39}$

DeWolf used the results from the aforemen-

37. See, for example, Philip Kotler, Marketing Manayement, 2nd ed. (Englewood Cliffs, N.J.: Prentice-Hall, 1972), pp. $669-670$.

38. Buchen Advertising. Inc., Advertising in Recession Perivds: 1949, 1954, 1958, 1961-A New Yardstick Revisited (Chicago, 1970).

39. See, for example, George A. Perce, "How kendali Prepartes Its Advertising Budges." in The Advertising Budget, Richard J. Kelly, ed. (New York: Association of National Advertiscrs, 1908), pp. 52.54 
tioned McGraw-Hill study of industrial firms' inarketing costs to establish a "yardstick that can apply to advertising budgets, present or proposed. to sec if they are of the proper magnitude." DeWolf recommended that if a company wanted to take full advantage of the potential of advertising, it shutld spend more than $20 \%$ of its marketing budget on advertising. As he put it, "the magic figure seems to be $20 \%$-until you get above $20 \%$, you are in the lower half of all companies in selling efficiently-and you can safely go up to at least 33\%."40

Much could be learned from a study of the determinants of industrial advertising expenditures. The question of why "advertising intensity" (measured by the ratio of advertising to sales) varies across product categories has attracted some attention from economists. ${ }^{41}$ However, this work appears to have been focused exclusively on consumer goods industries with no comparable analyses of data for industrial goods.

Other heuristics, such as "matching" competitive expenditures, also frequently enter into budgeting decisions. All of these methods share some common characteristics in that they serve as a management control device but are difficult to justify. Reliance on simple rules of thumb by industrial marketers appears to have declined over time. A 1939 survey of industrial advertising budgeting practices reported by Burden showed greater use of such methods than was indicated by the 1968 Industrial, Marketing study mentioned above. ${ }^{42}$

\section{Task Method}

The task method focuses on communication rather than on sales effects of advertising. A budget is developed by summing estimates of the costs of activities and programs required to accomplish the particular functions assigned to advertising. The essential steps involved in applying the method are:

1. Establish specific marketing objectives for the product in terms of factors such as sales volume, market share, and profit contribution, as well as target market seginents.

2. Assess the communication functions that

40) Sohn W. De Wolf, "A New Tool for settung and Selling Adventising Budpets" (Paper presented at the Essicrn Re. gronal Merting of the American Asseciation of Advertising Agencies, November 7,1963$), \mathrm{p} .21$

41. Lester G. Telser, "Some Aspects of the Economies of Advertising, Joumal of Busmess, Vol. 41 (April lons). pp. 106.173; and, for a review. see Sichmalensec, same reference as tootnote $10, \mathrm{pp} .18-20$

42. Neil H. Burden, The Economic Effects of Adversising (Chicage: Richard D. Irwin, 1942), p. 722. must be performed to realize the overall marketing objectives and determine the role of advertising and other elements of the communication mix in performung these functions.

3. Define specific goals for advertising in terms of the levels of measurable communication response required to achicve marketing objectives.

4. Estimate the budget needed to accomplish advertising goals.

Underlying the task method is the notion that the influence of advertising on buyers appears through some type of hicrarchy of effects ranging from creating product or company awareness and knowledge through developing favorable supplier or product attitudes and preferences. Implementation of these ideas grew markedly in the early 1960 s following the appearance of Colley's. oftcited volume on "DAGMAR."43 Several examples of applications of this version of the task method and the accompanying use of intermediate measures of communication effectiveness in industria! advertising have been discussed in the literature. $^{44}$ Industrial Marketing's 1968 survey found that users of the task method were more likely to be satisfied with their budgeting practices than respondents who relied on other approaches..$^{4.5}$

The practical difficulty of isolating advertising's impact on sales, plus roognition that advertising's function is to communicate, have motivated adoption of the task method and accompanying measures of intermediate response. The latter provide a basis for some modicum of management control over advertising operations. The great stumbling block in using this approach as a planning tool, however, is that it requires knowledere about how levels of expenditures and various communication response measures are related, and low the latter are linked to the purchase behavior that is relevant to the attainment of marketing goals. ${ }^{46}$ The existence and nature of

43. Russell H. Colley. Defining Advertising Goals for Mea. sured Advertising Resulfs (New York: Association of National Advertisets, $|\varphi 6|)$.

44. William P. Raines, "Setting Advertising Goals for In. dustrial Products," in The Advertising Budget, Richard J. Kellv, ed. (New York: Associalion of National Advertisers, 1968). pp. 47.51: Patrick J. Robinson and David J. Lusk, Promotional Decision Making (New York: McGraw-Hill Book Co., 1964). pp. 168-177; Saul s. Sands. Setfing ddvertising Objectives (New York: National Industrial Conference Board, 1906): and Wolfe et al., same reference as footnute 19.

45. Same reference as footnote 32, p. 68 .

46. See, for example, the papers on "Advertising Rescarch-DACMAR Revisited," in New Directions in Mar- 
such relationships are highly controversial matters. ${ }^{47}$ Progress is being made in understanding and using these relationships for purposes of planning and controlling marketing communications, but these developments appear to have occurred largely in the consumer fieldi. ${ }^{48}$

\section{Conclusions}

A review of the existing literature offers some insight into the existence of economies of scale; threshold effects, and interaction effects in the field of industrial advertising. It also points up the need for additional research in this area.

Evidence exists that supports the notion of economies of scale in industrial advertising, that is, that in some region of advertising expenditure, additional increments of advertising yield increasing returns. However, evidence has also been found that is not supportive of this hypothesis. Definitive information about the existence and location of this region would be of great help to budgeters in determining the level of advertising expenditures.

The existence of threshold effects, a minimum level of exposure needed for advertising to have a measurable effect, is supported by the literature. A manager should not expect to see advertising offects until the level of expenditure is sufficiently high. But where that threshold is found has not been established.

Finally, despite methodological problems in many of the studies, the volume of evidence suggests that industrial advertising and personal selling perform complementary and synergistic roles. Most managers might expect that a split of the industrial marketing budget between advertising and personal selling categories would be more

\footnotetext{
keting, Frederick E. Webster, Jr., ed. (Chicago: American Marketing Assn., June 1965), pp. 333-358.

47. Kristian S. Palda, "The Hypothesis of a Hierarchy of Eflects: A Partial Evaluation," Jounial of Marketing Re. search, Vol. 3 (February 1966), pp. 13-25; and, Michael L. Ray, "Marketing Communications and the Hierarchy of Effects," in New Models for Communications Research, Petcr Clarke, ed (Beverly Hills, Calif.: Sage, 1974), pp. 147-176.

48. Michael L. Ray, "A Decision Sequence Analysis of Developments i.. Marketing Communications," JourNal OF MARKETING, Vol. 37 (January 1973), pp. 29-38.
}

efficient than a total allocation to a single category. But there is no indication about either what the overall budget should be or what split between advertising and personal selling expenditures would be most efficient.

Thus, the study of the effects of industrial advertising has not yet provided guidance to industrial advertisers faced with specific expenditure decisions, and current budgeting practice reflects the lack of knowledge about response. Simple heuristics and the task method are the most common budgeting approaches used. Both methods provide a control mechanism for spending, but they may lead to inappropriate policies.

This review points to the need for a betler understanding of how industrial advertising can be effective. A major field study of advertising response would be desirable, but the small size of industrial advertising budgets makes an upsurge of activity in this arca appear unlikely. Opportunities do exist, however, for econometric work concerned with developing response functions for individual firms. Another fruitful research direction is 10 identify and exploit managers' existing knowledge about advertising effectiveness, an approach Bowman and others have shown to be empirically valid in other decision areas. ${ }^{49}$ One such study is underway ${ }^{60}$ and may help provide a basis for new forms of industrial advertising norms and guidelines.

49. E. H. Bowman, "Consistency and Optimality in Managerial Decision Making." Aanagement Science, Vol. 9 (January 1963), pp. 310-321; and Howard Kunteuther, "Ex. tensions of Bowman's Theory of Managerial Decision Mak ing," Management Science, Vol. 15 (April 1969), pp. B 4i5-
434.

50. For details of the study, see Gary L. Lilien, "How Many Dollars for Industrial Advertising? Project ADVISOR" (Working Paper 735-74, Sloan School of Management, M.I.T., September 1974); and John D. C. Little and Gasy 1. Lilien, "How Much for Industrial Advertising?" (Talk beture the Advertising Research Foundation Conference, New York, Noveminer i8, 1974).

This paper was prepared with the support of a research grant made to M.I.T. for Project ADVISOR, a study of inclustrial inarketing communications funded by a group of participating companies and coordinated through the Association of National Advertisers. Thanks are due to Dunald Gluck and John D. C. Litlle for stimulating this work. 